\begin{tabular}{c|c|c|c|c|c|} 
DOI: http://dx.doi.org/10.21276/ap.covid19.2021.10.1.2 \\
Annals of Phytomedicine: An International Journal \\
http://www.ukaazpublications.com/publications/index.php \\
Print ISSN : 2278-9839 Online ISSN : 2393-9885
\end{tabular}

\title{
Herbs that heal: A scoping review on COVID-19 pandemic
}

\author{
Cheena Naik and Saidaiah Pidigam** \\ Medicinal and Aromatic Plants Research Station, Sri Konda Laxman Telangana State Horticultural University, Regional Station, Rajendranagar- \\ 500 030, Hyderabad, Telangana, India \\ *College of Horticulture, Sri Konda Laxman Telangana State Horticultural University, Mojerla-509 382, Telangana, India
}

\section{Article Info}

Article history

Received 10 May 2021

Revised 26 June 2021

Accepted 27 June 2021

Published Online 30 June 2021

\section{Keywords}

COVID-19

SARS-CoV-2

Cinnamon

Clove

Black pepper

Giloy

\begin{abstract}
The severe acute respiratory syndrome coronavirus-2 lead to the outbreak of COVID-19, succumbed millions of people across globe and still counting. As demonstrated scientifically, the potent protease enzyme of SARS-CoV-2 binds to angiotensin-converting enzyme 2 receptor in cells of infected human beings, leading to health complications, especially respiratory ailments along with cytokine storm. The ancient, traditional medicines treating successfully various antimicrobial and antiviral diseases based on herbs anticipated to emerge as potent therapeutics in treatment of COVID-19. Therefore, this current review is an attempt to discuss mainly on final health complications associated with COVID-19, the overview, major pharmaceutical compounds present, proven earlier therapeutic value, potent use of four widely used spices as inhibitors in respect of SARS-CoV-2 and the underlining mechanisms of pharmaceutical action of cinnamon, clove, black pepper and giloy and their products with the traditional, scientific, molecular docking and clinical studies based reports. The information reviewed may be aiding to discover potent natural alternative medicines in complete treatment of patients suffering from COVID-19.
\end{abstract}

\section{Introduction}

"Cytokine storm" is the word that represents the severe case of SARS-CoV-2 infection that leads to hyperinflammatory (reactive oxygen species (ROS) induction and their release along with nitrogen species) syndrome, acute respiratory distress syndrome, failure of kidneys, complications related to nerves system and cardiovascular system (Wang et al., 2020) and inflammation as well (Ye et al., 2020). In COVID patients, the angiocentric inflammation in lungs leads to constant inflammation in certain organs such as the heart, gut, liver, and brain (Wang et al., 2020). Otherwise, any other effective treatment that counters the "cytokine storm," would interfere with viral replication.

At present, the therapies used in COVID-19 treatment are antimalarial, antiviral and anti-inflammatory, etc. The similar pharmaceutical values are possessed by certain spices, which have proven their efficacy in various viral treatments, with almost no side effects, readily available in required quantities and with certain other advantages over English medicine (Moghadamtousi et al., 2015; Srinivasan, 2005). A severe acute respiratory syndrome is an unusual type of contagious pneumonia that is caused by SARS coronavirus. The use of common spices as immunity boosters and aniviral agents is gaining importance. An online survey revealed that $71.8 \%$ of people using kadha are combating infection by boosting their immunity with no side effects. Hence, spices have

Corresponding author: Dr. Pidigam Saidaiah

Associate Professor, Department of Genetics and Plant Breeding, College of Horticulture, Sri Konda Laxman Telangana State Horticultural University, Mojerla-509 382, Telangana, India E-mail: saidu_genetics@yahoo.co.in; drpidigam@gmail.com Tel.: +91-7780509322

Copyright () 2021 Ukaaz Publications. All rights reserved.

Email: ukaaz@yahoo.com; Website: www.ukaazpublications.com significant role to combat viral infections (Caterina et al., 2021). Even US FDA has approved several spice derived natural products possessing phenolic rich compounds for medical purpose in treating the human diseases (Srinivasan, 2005; Newman and Cragg, 2016), specific inhibitors of protease of SARS-CoV-2 (Umesh et al., 2020). Under the circumstances explained as above, we attempted this review to introduce the mechanism of action of four spices, cinnamon, clove, black pepper and giloy, their main role in treating the SARS-CoV-2 based on earlier investigations and clinical studies.

\section{Discussion}

\subsection{Clove}

Syzygium aromaticum L., Merr. and Perry is an evergreen tree from the family Myrtaceae, habituated to tropical climates. Being indigenous to spices island of Indonesia, now cultivated in many countries. The clove of commerce is dried aromatic fully grown unopened flower bud. Cloves are strongly pungent owing to eugenol. Over the years, it is mentioned in Ayurveda, Chinese traditional medicines (Bhowmik et al., 2012). With varied potencies, all the three forms, clove (dried bud), oleoresin and clove oil are used in traditional medicine for vivid ailment treatments such as respiratory and digestive disorders (Aisha et al., 2011; Banerjee et al., 2006). The previous literature studies also evidenced other remarkable properties, such as tiangiogenic (Zheng et al., 1992, Aisha et al., 2011), anticancer (Zheng et al., 1992; Aisha et al., 2011; Banerjee et al., 2006), antioxidant (Ogata et al., 2000), anti-inflammatory (Darshan et al., 2004), and antimutagenic activities (Miyazawa et al., 2001). Clove is the familiar culinary spice in folk medicine. Its ingredients have anti-inflammatory, antithrombotic, antiviral, immunostimulatory and antibacterial properties. Antimicrobial activities of clove, made its wider use in food industry. There is 
positive nod from FDA for safety of using clove buds, derived oil, extracted eugenol, and oleoresins as well for use in food industry (Vijayasteltar et al., 2016). Ogunwande et al. (2005) informed that WHO confirmed the dosage of daily maximum clove uptake (2.5 $\mathrm{mg}$ ) per kg body weight.

Cloves are originally whole dried buds and also used in the form of ground spice, and essential oil as well. Dried clove buds contain $20 \%$ essential oil, which is rich in eugenol, accounting for 70-90\%. The other main phytochemicals isolated from clove essential oil include eugenyl acetate, $\beta$-caryophyllene, and several sesquiterpenes (Zheng et al., 1992; Mittal et al., 2014), including acubebene, $\alpha$ copaene, and $\gamma$-and $\delta$-cadinene (Gopalakrishnan, 1984). Crategolic acid, vanillin, gallotannic acid, etc., are present in lesser amounts (Mittal et al., 2014). Eugenol and other constituents (methyl salicylate and methyl amyl ketone) are representing for aroma of cloves. Yield of the oil varies with the raw material, from $1 \%$ in stem and leaf to $17.46 \%$ in bud.

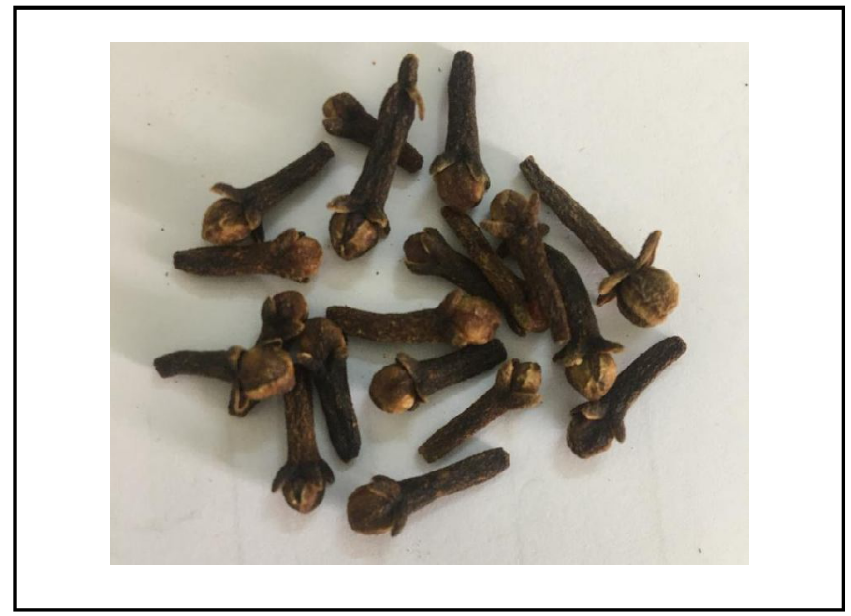

Figure 1: Dried mature flower buds of clove.

Table 1: Anti-inflammatory, immunostimulatory, and antithrombotic properties of clove and their products

\begin{tabular}{|c|c|c|}
\hline Product of clove & Medicinal property & References \\
\hline Clove essential oil & Anti-inflammatory effects in animal models & Öztürk and Ozbek, 2005 \\
\hline Clove bud ethanol extracts & Anti-inflammatory effects in animals & Öztürk and Ozbek, 2005 \\
\hline Eugenol & Anti-inflammatory activity - reduces pleural exudates in animals & Daniel et al., 2009 \\
\hline Eugenol & Regulate the cellular inflammatory cascade pathways & Bahramsoltani et al., 2020 \\
\hline $\begin{array}{l}\text { Whole clove aqueous extract } \\
\text { and eugenol }\end{array}$ & Relieves lipopolysaccharide induced lung inflammation & Magalhães et al., 2010 \\
\hline Clove aqueous extract & Protective effects pyelonephritis in animal models & Nassan et al., 2015 \\
\hline Clove aqueous extract & Curative action on kidney inflammation in COVID-19 patients & Su et al., 2020 \\
\hline Clove essential oil & The immunostimulatory activity & Carrasco et al., 2009 \\
\hline Clove buds & $\begin{array}{l}\text { Improve the blood supply to both the brain and the heart and } \\
\text { tonic for the cardiovascular system }\end{array}$ & Bahramsoltani et al., 2020 \\
\hline Clove oil & Human platelets enhancement & Saeed et al., 1994 \\
\hline Clove extracts & Inhibit the thrombin-induced platelet aggregation & Yang et al., 2011 \\
\hline Eugenol & Platelet inhibitor and preventing blood clots & García-Mediavilla et al., 2007 \\
\hline Eugenol & Clove anti-atherosclerotic potential & Yang et al., 2011 \\
\hline
\end{tabular}
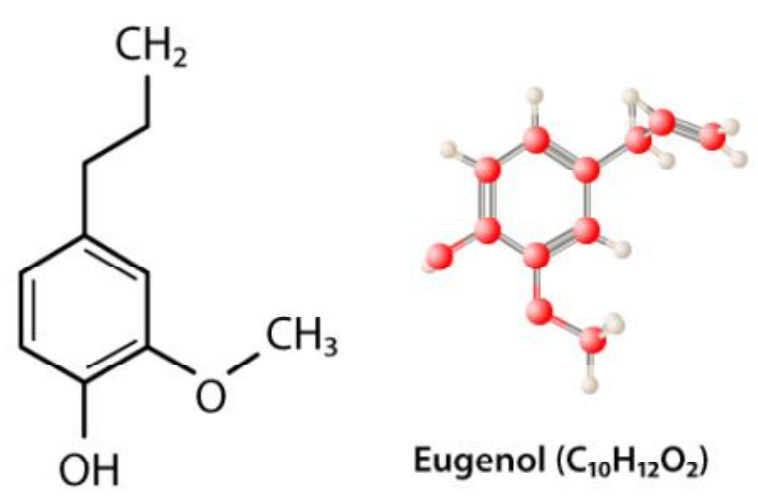

Eugenol $\left(\mathrm{C}_{10} \mathrm{H}_{12} \mathrm{O}_{2}\right)$

Figure 2: Structure of eugenol.

Traditional medicine uses cloves as respiratory aids, and in particular, the spice is one of the ingredients of teas used in tropical Asia to facilitate coughing (Bhowmik et al., 2012). Moreover, an aromatherapy procedure consisting of breathing in the aroma released from hot clove tea is another common way to use cloves for respiratory disorders like coughs, colds, asthma, bronchitis, and sinusitis (Bhowmik et al., 2012). Moreover, it is customary in Asia to chew cloves for treating soreness of throat and inflammation of the pharynx (Bhowmik et al., 2012).

The eugeniin inhibits DNA polymerase, the selective inhibitor of the HSV 1 (Kurokawa et al., 1998), thereby interfere in viral DNA synthesis and eugenol interfere with viral replication leading to reduced infection (Reichling et al., 2009).

Antiviral properties of clove: The whole clove antiviral activity was tested by Tragoolpua and Jatisatienr (2007), the ethanol extract of buds directly inactivated the standard HSV strains (Hussein et 
$a l ., 2000)$ reported that clove methanol extracts inhibited the HCV protease.

Among the products with antiviral properties, eugenol, 4-allyl-2methoxyphenol is the major constituent one. Tragoolpua and Jatisatienr (2007) used pure eugenol as the reference compound in their anti-HSV studies and found higher antiviral activity. Benencia and Courreges (2000) reported the eugenol inhibition of HSV-1 and HSV-2 replication. The study exhibited the eugenol as virucidal and no other element associated cytotoxicity was reported. Eugenol also showed antiviral activity against the influenza A virus (IAV) (Dai et al., 2013), inhibitor of the Ebola virus in vitro (Lane et al., 2019). While, eugeniin isolated from the herbal extracts of cloves showed anti-HSV activity (Kurokawa et al., 1998), which was due to the inhibition of the viral DNA synthesis. Eugeniin is the inhibitor of the protease of Dengue virus (DENV), and established as promising drug for DENV therapeutics (Saleem et al., 2019). Cloves are used in India and Morocco by herbalists for treatment and prevention of COVID-19 (Chaachouay et al., 2021). Kaempferol, a phytochemical compound in silico binds to the the main protease, via., substrate binding pocket of SARS-CoV-2 with high affinity and interacting with Cys145 and His41, which are the active site residues. This demonstrates that clove flavonoids can be potential SARS-CoV-2 inhibitors (Rehman et al., 2020). As revealed by the molecular docking, the intense affinities of clove extracts, i.e., bicornin applied at "9.2 kcal/mol and biflorin (" $8.5 \mathrm{kcal} / \mathrm{mol}$ ) for Mpro, leads to potential inhibitory activity (Rehman et al., 2020).

Clove is currently employed to prevent and control the SARS-CoV2-associated disease along with other herbs (Kanyinda, 2020). described the clove based protocol for COVID-19 treatment, especially when used at early stages of the viral infection.

Protocol: first cloves are put to boiling with water in mix with other herbs/material for $15 \mathrm{~min}$, administered to patients after its volative, active principle compounds are dissolved in water and same applies for drinkable clove decoction.

The therapeutic use of cloves in traditional medicine to treat respiratory ailments various viruses, in addition to antiinflammatory, immunostimulatory, and antithrombotic properties established clove potential with its phytochemical constituents against the COVID-19. There is the note of antibacterial effects exhibited by clove derived essential oils reducing the infections of immunosuppressed patients (Chaieb et al., 2007) and preventing secondary bacterial infections in COVID-19 patients (Bahramsoltani et al., 2020).

\subsection{Cinnamon}

Among the genuses, Cinnamomum those belongs to the family Lauraceae, the Ceylon cinnamon: Cinnamomum verum or $C$. zeylanicum has therapeutic values unlike Chinese cinnamon, Cinnamomum cassia or Cinnamomum aromaticum, which is used a culinary spice for foods (Oketch-Rabah et al., 2018). Presence of various compounds gives an idea about, of which cinnamaldehyde and eugenol are crucial. Leaves contain cinnamaldehyde of $1-5 \%$ and eugenol- 7 to $95 \%$, while cinnamaldehyde is reported to 65 to $80 \%$, eugenol varies from 5 to $10 \%$ in stem bark, root bark contains
$60 \%$ of camphor and eugenol content in leaf oil and bark oil ranges from 77.3-90.5\% and 4-10\%, respectively (Sangal, 2011; Vangalapati et al., 2012).

Its ethanolic extracts had anti-inflammatory activity which has antagonistic effect on the activation of TLR2 and TLR4 and has no effects on cell viability during culturing (Schink et al., 2018b). Transcinnamaldehyde, cinnamic acid, cinnamyl alcohol, cinnamyl methyl ether, p-cymene, methyl salicylate, 1-tetradecanol and benzoic acid are the active compounds in the extracts. Schink et al. (2018a) reported synergy with the anti-inflammatory properties in various compounds. The mixtures have good efficacy compared with pure active compounds. Cinnamaldehyde of cinnamon detoxifies ROS/ RNS by activation of NRF2 inducer (Long et al., 2015; Wondrak et al., 2010), while, another compound, cinnamaldehyde mitigates the PI3K/Akt pathway, thereby inhibit metastasis, angiogenesis (Patra et al., 2019). Lu et al. (2010) reported that the water based Ceylon cinnamon extracts inhibits VEGFR2 kinase. Ranasinghe et al. (2017) conducted the clinical safety of cinnamon in the form of toxicity and any associated side effects with respect to dosage applied and found no risks.

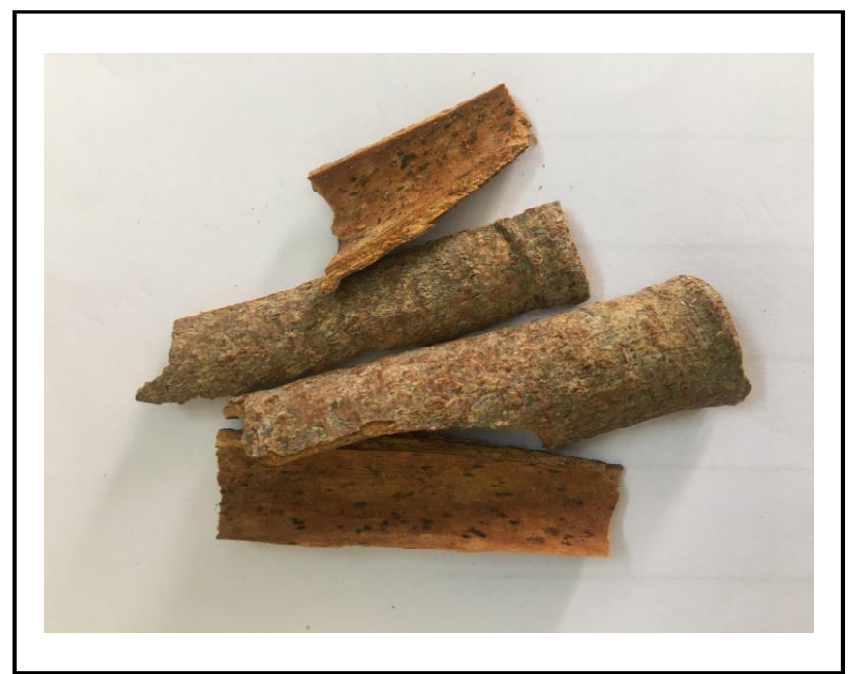

Figure 3: Cinnamon bark.

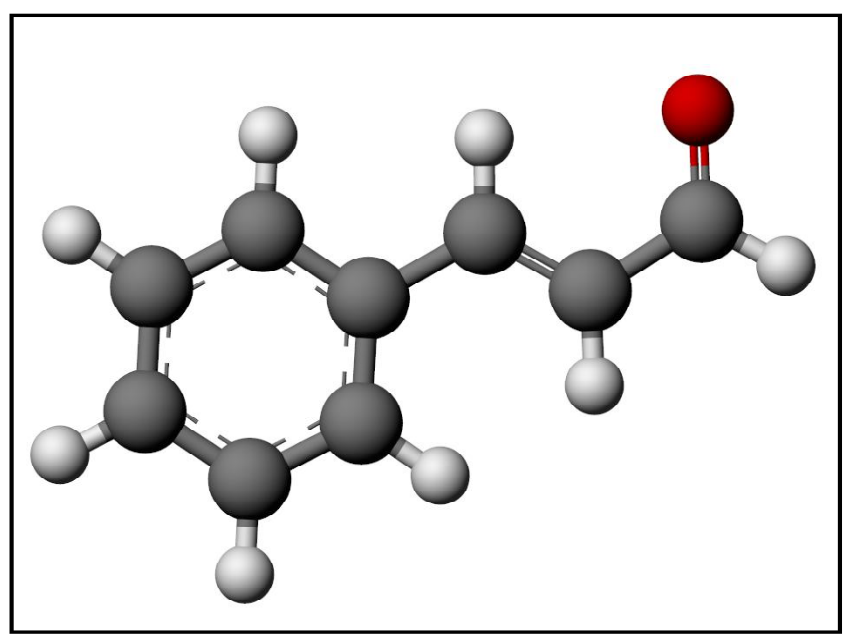

Figure 4: Structure of cinnamaldehyde. 
Table 2: Certain functions of cinnamon derivatives for various ailments

\begin{tabular}{|l|l|}
\hline Function of cinnamon product & References \\
\hline Anti-inflammatory functions & Schink et al., 2018a,b \\
Dampens pro-inflammatory cytokines release & Liu et al., 2019; Weber et al., 2019 \\
Angiogenesis, thrombosis, and vascular endothelialitis are inhibited & Xin et al., 2017; Patra et al., 2019 \\
Activates NRF2, mitigating ROS/RNS production leading to inflammation & Yao et al., 2015 \\
\hline
\end{tabular}

Ceylon cinnamon extracts would helpful in treating COVID-19 patients in combination with other medications. Dexamethasone use leads to atherosclerosis, which can be rectified with Ceylon cinnamon extract usage (Nayak et al., 2017). The bacterial pneumonia can be cured with the antibacterial effects of $C$. zeylanicum (Ranasinghe et al., 2013; Doyle and Stephens, 2019) and safe as well. Inflammatory complications are very common in covid patients (Portincasa et al., 2020; Heneka et al., 2020). Treating COVID-19 patients with cinnamon extracts could alleviate such complications, available at cheaper cost and easy to meet the required quantities. Individual compounds from cinnamon that have positive effect are provided in the list. The crucial regulator for proinflammatory cytokines cum transcription factor called NF- $\kappa B$ is activated and elicited by the extracts of Ceylon cinnamon (Schink et al., 2018b), thereby attributed with disease defense mechanism.

\subsection{Black pepper}

Balck pepper, Piper nigrum L., known as the 'king of spices' and 'black gold', belongs to family piperraceae. It's the most widely used and important spice of the world. The dried, mature fruits are used as spice. Charaka and Susrutha, the ancient physicias referred its medicinal values. The Greek physicians described the medical values of black pepper in Materia Medica. Around 135 compounds are reported in pepper essential oil. Black pepper contains phenolics such as phenolic acid, glycosides and flavonol glycosides. Black pepper is one of the important drugs in Indian systems of medicines. The alkaloid, piperine chemically 1 peperoyl piperidine is the major constituent, which is pungent in nature and possessing pharmacological values such as anti-inflammatory, antioxidant, antiplatelets, antihypertensive, anti-Alzheimer's, antidepressant, antimicrobial, germicide, carminative, anthelmentic, etc. (Jafri et al., 2019; Tiwari, et al., 2020; Yoo et al., 2019). It is used in Ayurveda, Siddha, Unani, and Tibetan, traditional medicine systems.

Table 3: Certain effects of product of black pepper

\begin{tabular}{|c|c|c|}
\hline $\begin{array}{l}\text { Product of } \\
\text { black pepper }\end{array}$ & Activity & References \\
\hline Piperamides & $\begin{array}{l}\text { Inhibition of coxsackie } \\
\text { virus type B3 }\end{array}$ & Mair et al., 2016 \\
\hline Aqueous extract & $\begin{array}{l}\text { Potent modulator of the } \\
\text { macrophages and enhanced } \\
\text { splenocyte proliferation }\end{array}$ & $\begin{array}{l}\text { Majdalawieh and } \\
\text { Carr, } 2010\end{array}$ \\
\hline Isolated alkaloid & $\begin{array}{l}\text { Anti-inflammatory effect } \\
\text { in RAW } 264.7 \text { cells }\end{array}$ & Pei et al., 2020 \\
\hline Isolated alkaloid & $\begin{array}{l}\text { Anti-allergic and anti- } \\
\text { asthma activities }\end{array}$ & Bui et al., 2020 \\
\hline
\end{tabular}

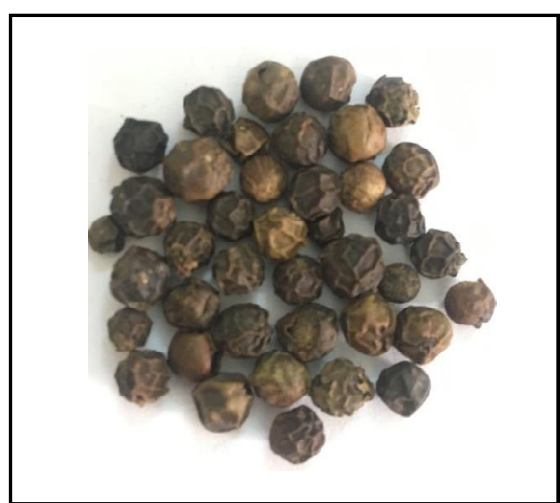

Figure 5: Black pepper.

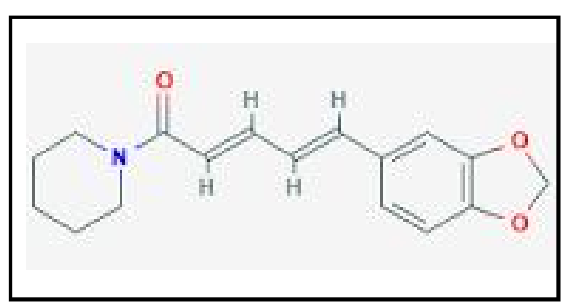

Figure 6: Structure of piperine.

The daily limited consumption of black pepper along with ginger helps in preventing coronavirus (Rajagopal et al., 2020). As per the report of Pathak and Khandelwal (2007), the use of pepper gives relaxation from COVID-19 symptoms. Yao et al. (2015) reported that quercetin, flavonoid of Black pepper are having antiviral properties and helps in boosting body immunity power. The antiviral activity of Balck pepper against vesicular stomatitis virus, human para-influenza virus on human cell lines with higher alkaloid content was more in chloroform extract (Priya and Saravana, 2017). According to molecular docking investigations, piperine inhibits methyltransferase of Dengue virus and effective against Ebola virus compared to Ribavirin (Nag and Chowdhury, 2020) and against COVID-19 due to piperdardine plus piperanine (Rajagopal et al., 2020). In molecular docking study against SARS-CoV-2, piperine showed high binding affinity $(-7.0 \mathrm{kCal} / \mathrm{mol})$ for RNA-binding pocket, the simulation confirmed the piperine as potential inhibitor of the RNA-binding site. Therefore, piperine seems to be potential candidate to inhibit the packaging of RNA and inhibiting the viral proliferation (Choudhary et al., 2020). Piperine is an inhibitor of hepatic and intestinal glucuronidatio, leading to enhanced (2000 times) bioavailability of curcumin (Roshdy et al., 2020).

\subsection{Tinospora cordifolia (Giloy and Guduchi)}

The medicinal plant, Tinospora cordifolia (Thunb). Miers from the family Meni-spermaceae. The other names are: giloy, guduchi, vatsaadani, amritavalli, madhuparni,amrita, amritalataa, chinnaruu 
-haa, chinnodbhavaa, tantrikaa, guduchi sattva (ayurveda) and giloy (folk). Tinospora is also mentioned in herbal ingredient of "soma" or "heavenly elixir" meaning food for immortals, as per Rigveda) (Khare, 2007; Mishra and Kaur, 2013; Leonti and Casu, 2014). T. cordifolia is also known as "nectar of life", as it strengthens the body immune system. It is distributed in Asian counties, almost all parts (stem, leaves, seed, root, flower) of the giloy have pharmaceutical values and are used in traditional medicine to cure diseases such as, urinary infections, skin allergies, jaundice, diabetes, inflammation, allergies, anemia, etc. (Kumar, 2020). Giloy is very unique boosting the body immunity and resistance against infections, hence, used as ayurvedic medicines since 1000s of years (Panchabhai et al., 2008). Recently, there is spike in direct use of herbal based formulations in treatment of ailments. WHO is also been encouraging to converge herbal medicine with modern medicine to have effective combat with ailments (WHO, 2019). Tinocordioside, magnoflorine, syringin, cordifolioside are the phytonutrients present in tinospora equipped with immunomodulatory pharmaceutical values (Sharma et al., 2019). Phytochemistry of all parts of guduchi is robustly documented in early writings (Sharma et al., 2019).

Table 4: Antiviral properties of certain reports of products of giloy

\begin{tabular}{|c|c|c|c|}
\hline Product of giloy & Activity of product & Target/organism & References \\
\hline T. cordifolia silver nanoparticles & Antiviral potential & Chikungunya virus cell & Sharma et al., 2019 \\
\hline $\begin{array}{l}\text { Alcoholic leaves extract of } \\
T \text {. cordifolia }\end{array}$ & $\begin{array}{l}\text { Decreases intracellular reactive } \\
\text { oxygen species (ROS) }\end{array}$ & $\begin{array}{l}\text { Chikungunya patients with high } \\
\text { levels of intracellular ROS }\end{array}$ & Banerjee et al., 2018 \\
\hline $\begin{array}{l}\text { Crude stem extract of } \\
\text { T. cordifolia }\end{array}$ & Antiviral potential & $\begin{array}{l}\text { Against HSV in Vero cell lines } \\
\text { by inhibiting the growth of HSV }\end{array}$ & $\begin{array}{l}\text { Pruthvish and Gopinatha, } \\
2018\end{array}$ \\
\hline $\begin{array}{l}\text { Aqueous extract of } T \text {. cordifolia } \\
\text { stem }\end{array}$ & $\begin{array}{l}\text { Immunomodulatory potential } \\
\text { and increase INF } \gamma \text { and IL } \\
\text { levels (IL-1, IL-2, IL-4) }\end{array}$ & Infectious bursal disease virus & Sachan et al., 2019 \\
\hline $\begin{array}{l}\text { Hydro-alcoholic extract of } \\
\text { T. cordifolia stem }\end{array}$ & $\begin{array}{l}\text { Cellular immunity as well as } \\
\text { humoral immunity }\end{array}$ & Broiler chicks & Nety et al., 2017 \\
\hline Chloroform extract & $\begin{array}{l}\text { prevented pro-inflammatory } \\
\text { biomarkers }\end{array}$ & RAW264.7 macrophages & Philip et al., 2018 \\
\hline
\end{tabular}

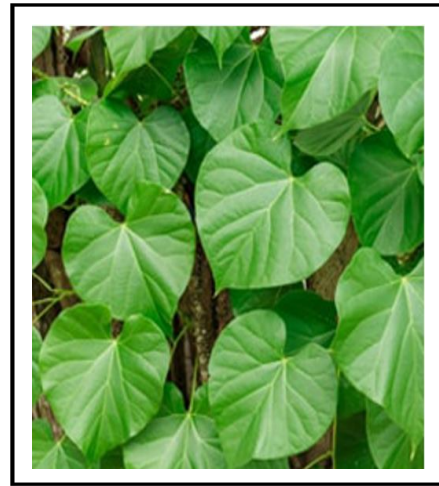

Figure 7: Giloy leaves.

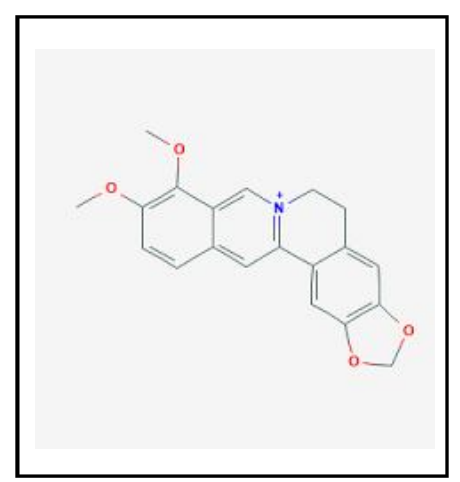

Figure 8: Structure of berberine.
T. cordifolia is a shrub with climbing nature. These plants are avaible in distribution in sub-tropical and tropical regions of the world. No much work is attempted in this shrub but the members of family have exhibited anti-inflammatory activity, antidiabetic, immunestimulatory, antioxidant, phagocytosis due to steroids, terpenes, alkaloids and polysaccharides (Sharma et al., 2012; Kapil and Sharma, 1997; Tiwari et al., 2014; Sharma et al., 2013; Imtiyaj Khan et al., 2011; Panchabhai et al., 2008). The stem of guduchi forms a strong base for treating leprosy, helminthiasis, rheumatoid arthritis, heart ailments. It improves immune system and supports production of regular white blood cells along with its levels, structure and function (Sharma et al., 2019). T. cordifolia is used in ayurveda to treat sporadic fever, urinary, skin, and eye ailments (Chi et al., 2016). In chicks, the stem aqueous extract of giloy has developed immunity against bursal disease (Sachan et al., 2019). The Patanjali Ayurveda Limited, India has commercialized the giloy aqueous extracts and manufacturing the tablets, branded as giloy ghanvati. Rastogi et al. (2020) recommended the use of $T$. cordifolia as it is loaded with compounds with antiviral properties. The giloy dry stem crude extract exhibited antiviral activity on HSV (Herpes Simplex Virus) (Pruthvish and Gopinatha, 2018). Berberine can regulate 3CLpro protein's function, thereby controls viral replication (Chowdhury, 2020). Tinocordiside from giloy inhibits protease in respect of SARS-CoV-2 (Shree et al., 2020). Berberine, isocolumbin, tinocordiside, and magnoflorine are the active compounds of giloy, which are with high binding affinity against the key glycoproteins, which are crucial for attachment and replication of SARS-CoV-2 virus particles (Sagar and Kumar, 2020). The aqueous extracts of $T$. cordifolia as giloy ghanvati reported as phenotype amelioration of COVID-19 virus, when used with humanized zebrafish model. It also reversed the spiked protein in 
respect of SARS-CoV-2 which demonstrates the positive correlation of its effectivess with the phytochemical present in giloy ghanvati and their importance in virus elimination (Balkrishna et al., 2021). Molecular docking revealed that tinocordiside at the dose of 8.10 kcal per mol from T. cordifolia is the anticipated inhibitors of main protease working against SARS-CoV-2 $\mathrm{M}^{\text {pro }}$ and are safe with drug like mechanism based on prediction of ADMET profile of phytochemical and stable based on MD stimulation investigation. This study also suggested the medicinal plants potentially alleviate Mpro of SARS-CoV-2 (Shree et al., 2020). The in silico and molecular docking revealed that phytochemical, berberine from guduchi can restrict the virus as it has potent to inhibit functions of $3 \mathrm{CL}^{\text {pro }}$ protein and which may the reason for its wide use in treating jaundice and rheumatism, etc. (Chowdhury, 2020). In silico based docking of the ligands (secondary metabolites from guduchi) to inhibit main protease of SARS-CoV-2 confirms that ten metabolites including tinosporide and tinocordifolin are effective key molecules (Sampark et al., 2021).

\section{Conclusion}

From the review, we conclude that spices have a significant play against viral infections. Traditional systems of medicine have proved to be effective in treating various ailments without side effects as refereed in various earlier literatures. The cinnamon, clove, black pepper and giloy play a vital role in inhibition of main protein of SARS-CoV-2, thereby effective in controlling COVID -19 virus and other viral infections as well. The phytocompounds present in the above spices are crucial for their antiviral activity. However, further attention is required to explore the mode of action against lethal viruses and their effectiveness. And also conduct of extract based experiments with in cell cultures, encapsulated powder formulations and water extracts are ray of hope to exact administer of these spices to patients, while standardizing the treatment doses for COVID-19 patients. The molecular insights on the specific phytochemical interactions with SARS-CoV-2 protein targets will act as a platform to design drugs with optimized characteristics.

\section{Funding}

The present research did not receive any specific grant from funding agencies in the public, commercial, or not-for-profit sectors.

\section{Acknowledgments}

The authors' thanks various front line workers and doctors for their service rendered and investigators who worked on and working on herbal medicines to find better alternative therapeutics.

\section{Conflicts of interest}

The authors declare that there are no conflicts of interest relevant to this article.

\section{References}

Aisha, A.; Nassar, Z.; Siddiqui, M.; Abu-Salah, K.; Alrokayan, S.; Ismail, Z. and Abdul Majid, A. (2011). Evaluation of antiangiogenic, cytotoxic and antioxidant effects of Syzygium aromaticum L. extracts. Asian J. Biol. Sci., 4:282-290.

Bahramsoltani, R. and Rahimi, R. (2020). An evaluation of traditional Persian medicine for the management of SARS-CoV-2. Front. Pharmacol., 11:201-207.
Balkrishna, A.; Khandrika, L. and Varshney, A. (2021). Giloy Ghanvati (Tinospora cordifolia (Willd.) Hook. f. and Thomson) Reversed SARS-CoV-2 Viral Spike-Protein Induced Disease Phenotype in the Xenotransplant Model of Humanized Zebrafish. Front. Pharmacol., 12:635510. doi:10.3389/fphar.2021.635510.

Banerjee, N.; Saha, B. and Mukhopadhyay, S. (2018). Intracellular ROS generated in chikungunya patients with persisting polyarthralgia can be reduced by Tinospora cordifolia leaf extract. Virus Dis., 29(3):375-379. doi: $10.1007 / \mathrm{s} 13337-018-0465-1$

Banerjee, S.; Panda, C.K. and Das, S. (2006). Clove (Syzygium aromaticum L.), a potential chemopreventive agent for lung cancer. Carcinogenesis, 27:1645-1654.

Benencia, F. and Courreges, M. (2000). In vitro and in vivo activity of eugenol on human herpesvirus. Phytother. Res., 14:495-500.

Bhowmik, D.; Kumar, K.S.; Yadav, A.; Srivastava, S.; Paswan, S. and Dutta, A.S. (2012). Recent trends in Indian traditional herbs Syzygium aromaticum and its health benefits. J. Pharm. Phytochem., 1:13-22.

Bui, T. T., Fan, Y., Piao, C. H., Nguyen, T. V., Shin, D. U. and Jung, S. Y.(2020). Piper nigrum extract improves OVA-induced nasal epithelial barrier dysfunction via activating Nrf2/HO-1 signaling. Cell. Immunol. 351, 104035. doi:10.1016/j.cellimm.2019.104035.

Carrasco, F.R.; Schmidt, G.; Romero, A.L.; Sartoretto, J.L.; Caparroz-Assef, S.M.; Bersani-Amado, C.A. and Cuman, R.K.N. (2009). Immunomodulatory activity of Zingiber officinale Roscoe, Salvia officinalis L. and Syzygium aromaticum L. essential oils: Evidence for humor-and cell-mediated responses. J. Pharm. Pharmacol., 61:961-967.

Chaachouay, N.; Douira, A. and Zidane, L. (2021). COVID-19, prevention and treatment with herbal medicine in the herbal markets of Salé Prefecture, North-Western Morocco. Eur. J. Integrat. Med., 42: 101285 .

Chaieb, K.; Hajlaoui, H.; Zmantar, T.; Kahla-Nakbi, A.B.; Rouabhia, M.; Mahdouani, K. and Bakhrouf, A. (2007). The chemical composition and biological activity of clove essential oil, Eugenia caryophyllata (Syzigium aromaticum L. Myrtaceae): A short review. Phytother. Res., 21:501-506.

Chi, S.; She, G.; Han, D.; Wang, W.; Liu, Z. and Liu, B. (2016). Genus Tinospora: Ethnopharmacology, phytochemistry, and Pharmacology. $J$. Evid.Based Integr. Med., 1-32. doi:10.1155/2016/9232593.

Chniguir, A.; Zioud, F.; Marzaioli, V.; El-Benna, J. and Bachoual, R. (2019). Syzygium aromaticum aqueous extract inhibits human neutrophils myeloperoxidase and protects mice from LPS-induced lung inflammation. Pharm. Biol., 57:55-63.

Choudhary, P.; Chakdar, H.; Singh, D.; Selvaraj, C.; Singh, S. K.; Kumar, S. and Saxena, A. K. (2020). Computational studies reveal piperine, the predominant oleoresin of black pepper (Piper nigrum) as a potential inhibitor of SARS-CoV-2 (COVID-19). Current Science, 119(8). https://doi.org/10.18520/cs/v119/i8/1333-1342.

Chowdhury, P. (2020). In silico investigation of phytoconstituents from Indian medicinal herb 'Tinospora cordifolia (giloy)' against SARSCoV-2 (COVID-19) by molecular dynamics approach. Journal of biomolecular structure and dynamics, 1-18. Advance online publication, https://doi.org/10.1080/07391102.2020.1803968.

Dai, J.P.; Zhao, X.F.; Zeng, J.; Wan, Q.Y.; Yang, J.C.; Li, W. Z.; Chen, X. X.; Wang, G. F. and Li, K.S. (2013). Drug screening for autophagy inhibitors based on the dissociation of Beclin1-Bcl2 complex using BiFC technique and mechanism of eugenol on anti-influenza A virus activity. PLoS ONE, 8:e61026 
Daniel, A.N.; Sartoretto, S.M.; Schmidt, G.; Caparroz-Assef, S.M.; Bersani-Amado, C.A. and Cuman, R.K.N. (2009). Anti-inflammatory and antinociceptive activities A of eugenol essential oil in experimental animal models. Rev. Bras. Farm., 19:212-217.

Darshan, S. and Doreswamy, R. (2004). Patented antiinflammatory plant drug development from traditional medicine. Phytother. Res., 18:343-357.

Doyle, A. A. and Stephens, J.C. (2019). A review of cinnamaldehyde and its derivatives as antibacterial agents. Fitoterapia., 139:104405. doi: $10.1016 /$ j.fitote. 2019.104405

Gopalakrishnan, N.; Narayanan, C. and Mathew, A. (1984). Sesquiterpene hydrocarbons from clove oil. Lebensmittel-Wissenschaft+Technol., $17: 42-43$.

Heneka, M. T.; Golenbock, D.; Latz, E.; Morgan, D. and Brown, R. (2020). Immediate and long-term consequences of COVID-19 infections for the development of neurological disease. Alzheimers Res. Ther.,12:69. doi: 10.1186/s13195-020-00640-3.

Hussein, G.; Miyashiro, H.; Nakamura, N.; Hattori, M.; Kakiuchi, N. and Shimotohno, K. (2000). Inhibitory effects of Sudanese medicinal plant extracts on hepatitis C virus (HCV) protease. Phytother. Res.,14:510516

Imtiyaj Khan, M.; Sri Harsha, P. S. C.; Giridhar, P. and Ravishankar, G. A. (2011). Pigment identification, antioxidant activity, and nutrient composition of Tinospora cordifolia (willd.) Miers ex Hook. f \& Thoms fruit. Int. J. Food Sci. Nutr., 62(3):239-249. doi:10.3109/ 09637486.2010 .529069

Jafri, A.; Siddiqui, S.; Rais, J.; Ahmad, M. S.; Kumar, S.; Jafar, T. and Arshad, M. (2019). Induction of apoptosis by piperine in human cervical adenocarcinoma via ROS mediated mitochondrial pathway and caspase-3 activation. EXCLI Journal, 18:154-164.

Kanyinda, J.N.M. (2020). Coronavirus (COVID-19): A protocol for prevention and treatment (Covalyse $\left.{ }^{\circledR}\right)$. Eur. J. Med. Health Sci., 2: $1-4$.

Kapil, A., and Sharma, S. (1997). Immunopotentiating compounds from Tinospora cordifolia. J. Ethnopharmacol. 58(2), 89-95. doi:10.1016/S0378-8741(97)00086-X

Khare, C.P. (2007). Indian medicinal plants-an illustrated dictionary, 663 664. Springer, ISBN: 978-0-387-70637-5, 2007.

Kumar, A. (2020). Molecular docking of natural compounds from Tuls (Ocimum sanctum) and neem (Azadirachta indica) against SARSCoV-2 protein targets. Preprints, https://doi.org/10.21203/rs.3.rs$27151 / \mathrm{v} 1$

Kurokawa, M.; Hozumi, T.; Basnet, P.; Nakano, M.; Kadota, S.; Namba, T. and Shiraki,K. (1998). Purification and characterization of eugeniin as an antiherpesvirus compound from Geum japonicum and Syzygium aromaticum. The Journal of Pharmacology and Experimental Therapeutics, 284(2):728-735

Lane,T.; Anantpadma, M.; Freundlich, J.S.; Davey, R.A.; Madrid, P.B. and Ekins, S (2019). The natural product eugenol is an inhibitor of the ebola virus in vitro. Pharm. Res., 36:1-6. [PubMed]

Leonti, M. and Casu, S. L. (2014). Food of the immortals according to the Bower Manuscript (Kashmir, 6th century AD). J. Ethno-pharmacol, 155(1):373-386

Liu, X.; Bai, J.; Jiang, C.; Song, Z.; Zhao, Y. and Nauwynck, H. (2019). Therapeutic effect of Xanthohumol against highly pathogenic porcine reproductive and respiratory syndrome viruses. Vet. Microbiol., 238:108431. doi: 10.1016/j.vetmic.2019.108431.
Long, M.; Tao, S.; Rojo De La Vega, M.; Jiang, T.; Wen, Q. and Park, S. L. (2015). Nrf2-dependent suppression of azoxymethane/dextran sulfate sodium-induced colon carcinogenesis by the cinnamon-derived dietary factor cinnamaldehyde. Cancer Prev. Res. (Phila), 8:444454. doi: 10.1158/1940-6207.CAPR-14-0359.

Lu, J.; Zhang, K.; Nam, S.; Anderson, R. A.; Jove, R. and Wen, W. (2010). Novel angiogenesis inhibitory activity in cinnamon extract blocks VEGFR2 kinase and downstream signaling. Carcinogenesis, 31:481-488. doi: 10.1093/carcin/bgp292.

Magalhães, C.B.; Riva, D.R.; DePaula, L.J.; Brando-Lima, A.; Koatz, V.L.G.; LealCardoso, J.H.; Zin, W.A. and Faffe, D.S. (2010). In vivo anti-inflammatory action of eugenol on lipopolysaccharide-induced lung injury. J. Appl. Physiol., 108:845-851.

Mair, C., Liu, R., Atanasov, A., Schmidtke, M., Dirsch, V., and Rollinger, J. (2016). Antiviral and anti-proliferative in vitro activities of piperamides from black pepper. Planta Med., 81(S01):S1-S381.doi:10.1055/s0036-1596830

Majdalawieh, A. F., and Carr, R. I. (2010). In vitro investigation of the potential immunomodulatory and anticancer activities of black pepper (Piper nigrum) and cardamom (Elettaria cardamomum). J. Med. Food, 13(2):371-381. doi:10.1089/jmf.2009.1131

Mishra R. and Kaur, G. (2013). Aqueous ethanolic extract of Tinospora cordifolia as a potential candidate for differentiation based therapy of glioblastomas. PLoS ONE, 8(10), Article e78764.

Mittal, M.; Gupta, N.; Parashar, P.; Mehra, V. and Khatri, M. (2014). Phytochemical evaluation and pharmacological activity of Syzygium aromaticum: A comprehensive review. Int. J. Pharm. Pharm. Sci., 6:67-72.

Miyazawa, M. and Hisama, M. (2001). Suppression of chemical mutageninduced SOS response by alkylphenols from clove (Syzygium aromaticum) in the Salmonella typhimurium TA1535/pSK1002 umu test. J. Agric. Food Chem., 49:4019-4025.

Moghadamtousi, S.Z; Nikzad, S.; Kadir, H.A.; Abubakar, S. and Zandi, K. (2015). Potential Antiviral Agents from Marine Fungi: An Overview. Mar. Drugs, 13:4520-4538. https://doi.org/10.3390/md13074520.

Nag, A.; Chowdhury, R. R. (2020). Piperine, an alkaloid of black pepper seeds can effectively inhibit the antiviral enzymes of Dengue and Ebola viruses, an in silico molecular docking study. Virus Disease, 31(3):308-315.

Nassan, M.; Mohamed, E.; Abdelhafez, S. and Ismail, T. (2015). Effect of clove and cinnamon extracts on experimental model of acute hematogenous pyelonephritis in albino rats: Immunopathological and antimicrobial study. Int. J. Immunopathol. Pharmacol., 28:6068 .

Nayak, I. N.; Chinta, R. and Jetti, R. (2017). Anti-atherosclerotic potential of aqueous extract of cinnamomum zeylanicum Bark against glucocorticoid induced atherosclerosis in wistar rats. J. Clin. Diagn. Res., 11:19-23. doi: 10.7860/JCDR/2017/23910.9864.

Nety, S., Koley, K. M., Choudhary, M., Chourasia, D. and Kumar, V. (2017). Comparative study of immunomodulatory effect of tinospora cordifolia stem and azadirachta indica leaf extract in broiler chicks. Vet. Pract., 18(2):286-288

Newman, D. J. and Cragg, G.M. (2016). Natural products as sources of new drugs from 1981 to 2014, J. Nat. Prod., 79:629-61.

Ogata, M.; Hoshi, M.; Urano, S. and Endo, T. (2000). Antioxidant activity of eugenol and related monomeric and dimeric compounds. Chem. Pharm. Bull., 48:1467-1469.

Ogunwande, I.; Olawore, N.; Ekundayo, O.; Walker,T. M.; Schmidt, J. M. and Setzer, W. N. (2005). Studies on the essential oils composition, antibacterial and cytotoxicity of Eugenia uniflora L. International Journal of Aromatherapy, 15:147-152. 
Oketch-Rabah, H. A.; Marles, R. J. and Brinckmann, J. A. (2018). Cinnamon and cassia nomenclature confusion: a challenge to the applicability of clinical data. Clin. Pharmacol. Ther., 104:435-445. doi: 10.1002/ cpt.1162.

Öztürk, A. and Özbek, H. (2005). The anti-inflammatory activity of Eugenia caryophyllata essential oil: An animal model of antiinflammatory activity. Eur. J. Gen Med., 2:159-163.

Panchabhai, T. S.; Kulkarni, U. P. and Rege, N. N. (2008). Validation of therapeutic claims of Tinospora cordifolia: A review. Phytother. Res., 22(4):425-441. doi:10.1002/ptr.2347.

Pathak, N. and Khandelwal, S. (2007). Cytoprotective and immunomodulating properties of piperine on murine splenocytes: An in vitro study. European Journal of Pharmacology, 576:160-170.

Patra, K.; Jana, S.; Sarkar, A.; Mandal, D. P. and Bhattacharjee, S. (2019). The inhibition of hypoxia-induced angiogenesis and metastasis by cinnamaldehyde is mediated by decreasing HIF- $1 \alpha$ protein synthesis via PI3K/Akt pathway. Biofactors, 45:401-415. doi: 10.1002/ biof.1499.

Pei, H.; Xue, L.; Tang, M.; Tang, H.; Kuang, S. and Wang, L. (2020). Alkaloids from black pepper (piper nigrum L.) exhibit anti-inflammatory activity in murine macrophages by inhibiting activation of $\mathrm{NF}-\kappa \mathrm{B}$ pathway. J. Agric. Food Chem., 68(8), 2406-2417.doi:10.1021/acs. jafc. 9 b07754

Philip, S., Tom, G., and Vasumathi, A. V. (2018). Evaluation of the antiinflammatory activity of Tinospora cordifolia (Willd.) Miers chloroform extract - a preclinical study. J. Pharm. Pharmacol., 70(8), 1113-1125. doi: $10.1111 /$ jphp. 12932

Pinto, C.; Cestero, J. J.; Rodríguez-Galdón, B. and Macías, P. (2014). Xanthohumol, a prenylated flavonoid from hops (Humulus lupulus L.), protects rat tissues against oxidative damage after acute ethanol administration. Toxicol. Rep., 1:726-733.doi:10.1016/ j.toxrep.2014.09.004.

Portincasa, P.; Krawczyk, M.; Machill, A.; Lammert, F. and Di Ciaula, A. (2020). Hepatic consequences of COVID-19 infection. Lapping or biting? Eur. J. Intern. Med., 77:18-24. doi: 10.1016/j.ejim.2020.05.035.

Prasad, S.; Tyagi, AK. and Aggarwal, BB. (2014). Recent Developments in Delivery, Bioavailability, Absorption and Metabolism of Curcumin: the Golden Pigment from Golden Spice. Cancer Res. Treat., 46:218

Priya, N.C. and Saravana, K. (2017). Antiviral activities and cytotoxicity assay of seed extracts of Piper longum and Piper nigrum on human cell lines. International Journal of Pharmaceutical Sciences Review and Research, 44(1):197-202.

Pruthvish, R. and Gopinatha, S. M. (2018). Antiviral prospective of Tinospora cordifolia on HSV-1. International Journal of Current Microbiology and Applied Sciences, 7(01):3617-3624. https://doi.org/10.20546/ ijcmas.2018.701.425

Pruthvish, R. and Gopinatha, S.M. (2018). Antiviral prospective of Tinospora cordifolia on HSV-1. Int. J. Curr. Microbiol. Appl. Sci., 7(1), $3617-$ 3624. doi:10.20546/ijcmas.2018.701.425

Rajagopal, K.; Byran, G.; Jupudi, S. and Vadivelan, R. (2020). Activity of phytochemicalconstituents of black pepper, ginger, and garlic againstcoronavirus (COVID-19): An in silico approach. International Journal of Health and Allied Sciences, 9:43-50.

Ranasinghe, P.; Jayawardena, R.; Pigera, S.; Wathurapatha, W. S.; Weeratunga, H. D. and Premakumara, G. (2017b). Evaluation of pharmacodynamic properties and safety of Cinnamomum zeylanicum (Ceylon cinnamon) in healthy adults: A phase I clinical trial. BMC Complement. Altern. Med., 17:550.doi:10.1186/s12906-017-2067-7.
Ranasinghe, P.; Pigera, S.; Premakumara, G. A.; Galappaththy, P.; Constantine, G R. and Katulanda, P. (2013). Medicinal properties of 'true' cinnamon (Cinnamomum zeylanicum): a systematic review. BMC Complement. Altern. Med., 13:275.doi:10.1186/1472-6882-13-275.

Rastogi, S.; Pandey, D.N. and Singh, R.H. (2020). COVID-19 pandemic: A pragmatic plan for ayurveda intervention. Journal of Ayurveda and Integrative Medicine, https://doi.org/10.1016/j.jaim.2020.04.002.

Rehman, M.; AlAjmi, M.F. and Hussain, A. (2020). Natural compounds as inhibitors of SARS-CoV-2 main protease (3CLpro): A molecular docking and simulation approach to combat COVID-19. Curr. Pharm. Des., 16.

Reichling, J.; Schnitzler, P.; Suschke, U. and Saller, R. (2009). Essential oils of aromatic plants with antibacterial, antifungal, antiviral, and cytotoxic properties-an overview. Forsch Komplementmed, 16:7990 .

Roshdy, W.H.; Rashed, H.A; Kandeil,A.; Mostafa, A.; Moatasim, Y. and Kutkat, O. (2020). EGYVIR: An immunomodulatory herbal extract with potent antiviral activity against SARS-CoV-2. PLoS ONE, 15(11): e0241739. https://doi.org/ 10.1371/journal.pone.0241739

Sachan, S.; Dhama, K.; Latheef, S.K.; Samad, H.A.; Mariappan, A.K. and Munuswamy, P. (2019). Immunomodulatory potential of tinospora cordifolia and $\mathrm{CPG}$ ODN (TLR21 agonist) against the very virulent, infectious bursal disease virus in SPF chicks. Vaccines, 7(3),106. doi:10.3390/vaccines 7030106

Saeed, S.A. and Gilani, A.H. (1994). Antithrombotic activity of clove oil. J. Pak. Med. Assoc., 44:112.

Sagar, V.K. and Kumar, A.H.S. (2020). Efficacy of natural compounds from Tinospora cordifolia against SARS-CoV-2 protease, surface glycoprotein and RNA polymerase. Preprint., https://doi.org/ 10.21203/rs.3.rs-27375/v1

Saleem,H.N.; Batool, F.; Mansoor, H.J.; Shahzad-ul-Hussan, S. and Saeed, M. (2019). Inhibition of dengue virus protease by Eugeniin, Isobiflorin, and Biflorin Isolated from the Flower Buds of Syzygium aromaticum (Cloves). ACS Omega, 4:1525-1533.

Sampark, S.; Thakkar ; Foram, S.; Parth, T. (2021). Magical bullets from an indigenous Indian medicinal plant Tinospora cordifolia: An in silico approach for the antidote of SARS-CoV-2. Egyptian Journal of Petroleum, 30(1):53-66. https://doi.org/10.1016/j.ejpe.2021.02. 005 .

Sangal, A. (2011). Role of cinnamon as beneficial antidiabetic food adjunct: A review," Advances in Applied Science Research, 2(4):440-450.

Schink, A.; Naumoska, K.; Kitanovski, Z.; Kampf, C. J.; Fröhlich-Nowoisky, J. and Thines, E. (2018a). Anti-inflammatory effects of cinnamon extract and identification of active compounds influencing the TLR2 and TLR4 signaling pathways. Food Funct., 9:5950-5964. doi: 10.1039/ C8FO01286E.

Schink,A.; Neumann, J.; Leifke,A. L.; Ziegler, K.; Fröhlich-Nowoisky, J. and Cremer, C. (2018b). Screening of herbal extracts for TLR2- and TLR4-dependent anti-inflammatory effects., PLoS ONE, 13:e0203907. doi: 10.1371/ journal.pone.0203907.

Sharma, P.; Dwivedee, B. P.; Bisht, D.; Dash, A. K. and Kumar, D. (2019). The chemical constituents and diverse pharmacological importance of Tinospora cordifolia. Heliyon, 5(9):e02437. 10.1016/j.heliy on. 2019 e 02437

Sharma, R.; Martins, N.; Kuca, K.; Chaudhary, A.; Kabra, A. and Rao, M. M. (2019). Chyawanprash: A traditional indian bioactive health supplement. Biomolecules, 9(5):161. doi:10.3390/biom9050161. 
Sharma, R.; Kumar, V.; Galib, R.; Prajapati, P.; Ravishankar, B. and Ashok, B. (2013). Evaluation of hypoglycaemic and anti-hyperglycaemic activities of Guduchi Ghana in Swiss albino mice. Int. J. Green. Pharm., 7(2):145. doi:10.4103/0973-8258.116397.

Sharma, U.; Bala, M.; Kumar, N.; Singh, B.; Munshi, R. K. and Bhalerao, S. (2012) Immunomodulatory active compounds from Tinospora cordifolia. J. Ethnopharmacol., 141(3):918-926. doi:10.1016/j.jep.2012.03. 027.

Shree, P.; Mishra, P.; Selvaraj, C.; Singh, S. K.; Chaube, R.; Garg, N. and Bhusan Tripathi, Y. (2020). Targeting COVID-19 (SARS-CoV-2) main protease through active phytochemicals of ayurvedic medicinal plants Withania somnifera (Ashwagandha), Tinospora cordifolia (Giloy) and Ocimum sanctum (Tulsi) - A molecular docking study. Journal of Biomolecular Structure and Dynamics, pp:1-14. https://doi.org/ 10.1080/07391102.2020.1810778.

Srinivasan, K. (2005). Role of Spices beyond food flavoring: nutraceuticals with multiple health effects, Food Rev. Int., 21:167-88.

Su, H.; Yang, M.; Wan, C.; Yi, L.-X.; Tang, F.; Zhu, H.-Y.; Yi, F.; Yang, H.-C.; Fogo, A.B. and Nie, X. (2020). Renal histopathological analysis of 26 postmortem findings of patients with COVID-19 in China. Kidney Int., 98:219. 227

Tanko, Y.; Mohammed, A.; Okasha, M.; Umah, A. and Magaji, R. (2008). Antinociceptive and anti-inflammatory activities of ethanol extract of Syzygium aromaticum flower bud in wistar rats and mice. Afr. J. Trad. Complement. Altern. Med., 5:209-212.

Tiwari, A.; Mahadik, K. R. and Gabhe, S. Y. (2020). Piperine: A comprehensive review of methods of isolation, purification, and biological properties. Medicine in Drug Discovery, 7:100027.

Tiwari, M.; Dwivedi, U. N. and Kakkar, P. (2014). Tinospora cordifolia extract modulates COX-2, iNOS, ICAM-1, pro-inflammatory cytokines and redox status in murine model of asthma. J. Ethnopharmacol., 153(2):326-337. doi:10.1016/j.jep.2014.01.031.

Tragoolpua, Y. and Jatisatienr, A. (2007). Anti-herpes simplex virus activities of Eugenia caryophyllus (Spreng.) Bullock and SG Harrison and essential oil, eugenol. Phytother. Res., 21:1153-1158.

Umesh; Kundu, D.; Selvaraj, C.; Singh, S.K. and Dubey, V.K. (2020). Identification of new anti-nCoV drug chemical compounds from Indian spices exploiting SARS-CoV-2 main protease as target, J. Biomol. Struct. Dyn., 1:1-7.

Vangalapati, M.; Sree Satya, N.; Surya Prakash, D. and Avanigadda, S. (2012). A review on pharmacological activities and clinical effects of cinnamon species. Research Journal of Pharmaceutical, Biological and Chemical Sciences, 3(1):653-663.
Vicidomini,C.; Roviello,V. and Roviello, G. N. (2021). Molecular Basis of the Therapeutical Potential of Clove (Syzygium aromaticum L.) and Clues to its Anti-COVID-19 Utility, Molecules, 10.3390/molecules 26071880,26,7,(1880),(2021).

Vijayasteltar, L.; Nair, G. G.; Maliakel, B.; Kuttan, R. and Krishnakumar, I. M. (2016). Safety assessment of a standardized polyphenolic extract of clove buds: Subchronic toxicity and mutagenicity studies. Toxicology Reports, 3:439-449.

Wang, T., Du, Z., Zhu, F., Cao, Z., An, Y. and Gao, Y. (2020). Comorbidities and multi-organ injuries in the treatment of COVID-19. Lancet, 395:e52. doi: $10.1016 / \mathrm{S} 0140-6736(20) 30558-4$

Weber, N.; Biehler, K.; Schwabe, K.; Haarhaus, B.; Quirin, K. W. and Frank, U. (2019). Hop extract acts as an antioxidant with antimicrobial effects against propionibacterium acnes and staphylococcus aureus. Molecules, 24:223. doi:10.3390/molecules24020223.

WHO (2019). WHO global report on traditional and complementary medicine. Geneva. World Health Organization.

Wondrak, G. T.; Villeneuve, N. F.; Lamore, S. D.; Bause, A. S.; Jiang, T. and Zhang, D. D. (2010). The cinnamon-derived dietary factor cinnamic aldehyde activates the Nrf2-dependent antioxidant response in human epithelial colon cells. Molecules, 15:3338-3355. doi: 10.3390/ molecules 15053338 .

Xin, G.; Wei, Z.; Ji, C.; Zheng, H.; Gu, J. and Ma, L. (2017). Xanthohumol isolated from Humulus lupulus prevents thrombosis without increased bleeding risk by inhibiting platelet activation and mtDNA release. Free Radic. Biol. Med., 108:247-257. doi: 10.1016/ j.freeradbiomed.2017.02.018

Yang, Y.Y.; Lee, M.J.; Lee, H.S. and Park, W.H. (2011). Screening of antioxidative, anti-platelet aggregation and anti-thrombotic effects of clove extracts. J. Physiol. Pathol. Korean Med., 25:471-481.

Yao, J.; Zhang, B.; Ge, C.; Peng, S. and Fang, J. (2015). Xanthohumol, a polyphenol chalcone present in hops, activating Nrf2 enzymes to confer protection against oxidative damage in PC12 cells. J. Agric. Food Chem., 63:1521-1531. doi: 10.1021/jf505075n.

Ye, Q., Wang, B., and Mao, J. (2020). The pathogenesis and treatment of the "Cytokine Storm" in COVID-19. J. Infect., 80:607-613. doi: 10.1016/j.jinf.2020.03.037.

Yoo, E. S.; Choo, G. S.; Kim, S. H.; Woo, J. S.; Kim, H. J.; Park, Y. S. and Jung, J. Y. (2019). Antitumor and apoptosis-inducing effects of piperine on human melanoma cells. Anticancer Research, 39(4):18831892. https://doi.org/10.21873/anticanres.13296.

Zheng, G.Q.; Kenney, P.M. and Lam, L.K. (1992). Sesquiterpenes from clove (Eugenia caryophyllata) as potential anticarcinogenic agents. J. Nat. Prod., 55:999-1003. 